\title{
Centralisatie van Zorg
}

\author{
M. T. W. T. Lock ${ }^{1}$
}

Published online: 4 September 2017

(c) The Author(s) 2017. This article is an open access publication.

Voor u ligt het themanummer 'Centralisatie van Zorg'. In 2013 schreef Bart Wijsman [1], huidig voorzitter van de NVU, in dit tijdschrift: "Concentratie van zorg betekent zaken niet meer doen en dit zal door menig uroloog worden opgevat als uitholling van het vak." In datzelfde nummer constateerden collegae Somford en Van Basten dat zij verwachtten dat een radicale prostatectomie ten gevolge van centralisatie niet meer zal behoren tot het arsenaal van de algemeen uroloog. Minder prettige conclusies, dachten veel perifeer werkende urologen, en hoopten dat de positieve verhalen van de Martinikliniek in Hamburg meer gezien moesten worden onder de noemer: 'één zwaluw maakt nog geen zomer'.

Maar wat is de werkelijkheid van dit moment? Henk van der Poel laat zien dat in 2016, in verreweg minder dan de helft van alle Nederlandse ziekenhuizen, nog een radicale prostatectomie werd gedaan. Patiënten die worden behandeld in ziekenhuizen met minder dan 100 prostatectomieën per jaar hebben significant meer bloedverlies tijdens een langere OK-tijd. Daarnaast was het overallpercentage positieve snijvlakken in de hoogvolumeklinieken $6 \%$ lager dan in de klinieken met een lager volume. Concentratie van zorg vindt dus al plaats en lijkt ook resultaten op te leveren!

Concentratie van peniscarcinoomzorg vindt al plaats sinds het laatste decennium van de vorige eeuw. Simon Horenblas maakt in zijn bijdrage duidelijk tot welke vele voordelen dit heeft geleid voor patiënt (hoogste overleving

drs. M. T. W. T. Lock

m.t.w.t.lock@umcutrecht.nl

1 Utrecht, Nederland in Nederland!) en kliniek. Deze concentratie van zorg heeft als voorbeeld gediend voor Engeland en Zweden.

Een Comprehensive Prostate Cancer Network (CPCN, geen Nederlands begrip mogelijk?) zien Van Basten en collegae als een samenwerkingsverband tussen zorgaanbieders in de eerste, tweede en derde lijn. Dit alles gericht op persoonlijke hoogwaardige prostaatkankerzorg in een brede regio. Een gelijk gestemd artikel is van de hand van Geboers en collegae. Beide groepen pleiten voor een verregaande regionalisatie en zeker geen totale centralisatie (twee centra in Nederland). Ook de patiëntenbelangenvereniging PKS pleit voor regionalisatie, maar noemen het expertcentra. De eisen die zij stellen, zijn niet mals! Minimaal 1000 patiënten screenen en minimaal 250 radicale prostatectomieën. Daarnaast minstens 50 ingrepen per operateur per jaar, maar liever 100 per jaar!

Prof. Wouter Feitz geeft zijn visie op de centralisatie van zorg binnen de kinderurologie. Hij pleit vooral voor breed kijken, dus vooral ook het buitenland (Europa) betrekken bij beleid en kennisuitwisseling. De nieuw op te leiden kinderurologen zullen daar zeker van profiteren.

Collegae Oddens en Boormans breken een lans voor steeds beter wordende oncologische zorg voor blaaskanker in Nederland. Het Integraal Kankercentrum Nederland (IKNL) heeft vastgesteld dat er in diverse regio's praktijkvariatie bestaat in de behandeling van het gelokaliseerd spierinvasief blaascarcinoom. De NVU heeft in haar beleidsplan 2015-2020 aangegeven deze praktijkvariatie zo veel mogelijk te willen beperken. Net als bij de prostaatcarcinoomzorg kunnen, door vergaande regionalisatie, alle blaaskankerpatiënten in een regio dezelfde (kwali- 
teits)behandeling krijgen. Een mooi voorbeeld is het Rotterdamse Blaaspoortproject.

Open Access This article is distributed under the terms of the Creative Commons Attribution 4.0 International License (http:// creativecommons.org/licenses/by/4.0/), which permits unrestricted use, distribution, and reproduction in any medium, provided you give appropriate credit to the original author(s) and the source, provide a link to the Creative Commons license, and indicate if changes were made.

\section{Literatuur}

1. Wijsman BP. Concentratie van zorg: een noodzaak in Nederland. Tijdschr Urol. 2013;3:30-2.

drs. M.T.W.T. Lock uroloog/androloog (in ruste) 